Jurnal Gizi dan Dietetik Indonesia (Indonesian Journal of Nutrition and Dietetics) Vol. 8, No. 1, 2020: 39-44
Available online at: http://ejournal.almaata.ac.id/index.php/IJND

DOI : http://dx.doi.org/10.21927/ijnd.2020.8(1).39-44

\title{
Does the consumption of local snacks on sale in the schools cause adolescent obesity? A case study in the secondary vocational schools
}

\author{
Muhammad Nur Hasan Syah ${ }^{1,2}$, Rani Dian Miranti², Noerfitri², Andi Imam Arundhana Thahir ${ }^{3}$
}

${ }^{1}$ Nutrition Department, Faculty of Health Science, University of Pembangunan Nasional Veteran Jakarta, Indonesia

${ }^{2}$ Nutrition Department, Mitra Keluarga School of Health Science Bekasi, Indonesia

${ }^{3}$ Nutrition Department, School of Public Health, Hasanuddin University Makassar, Indonesia

*Corresponding author: anca.gizi@gmail.com

\begin{abstract}
ABSTRAK
Latar belakang: Prevalensi kelebihan berat badan dan obesitas pada remaja (13 - 15 tahun) meningkat secara signifikan dari 7,3\% pada 2013 menjadi 13,5\% pada 2018. Ketersediaan restoran cepat saji yang semakin banyak, baik lokal maupun komersial, di sekitar sekolah semakin meningkatkan jumlah anak remaja usia sekolah yang terpapar makanan tidak sehat, terlebih bagi mereka yang tinggal di daerah perkotaan.

Tujuan: Penelitian ini menguji dampak camilan lokal yang tersedia di sekolah terhadap kejadian obesitas pada remaja.

Metode: Penelitian Ini menggunakan disain cross-sectional yang dilakukan di lima Sekolah Menengah Kejuruan (SMK) di Bekasi, Indonesia. Sebanyak 225 siswa berusia 16-18 tahun diamati status gizi dan konsumsi makanan ringan mereka. Indeks massa tubuh menurut usia (IMT/U) digunakan untuk menentukan status obesitas remaja. Diklasifikasikan sebagai obesitas apabila nilai z score > 2SD sesuai dengan usia dan jenis kelamin mereka, menggunakan grafik referensi WHO 2007. Siswa ditanya tentang konsumsi makanan mereka menggunakan kuesioner frekuensi makan (FFQ) semi kuantitatif. Odds ratio (OR) dihitung untuk setiap jenis makanan ringan dan nilai $p<0,05$ sebagai nilai signifikan secara statistik. Hasil: Temuan penelitian ini menunjukkan bahwa 32,4\% siswa mengalami obesitas. Konsumsi makanan ringan lokal yang terkait dengan obesitas termasuk makanan berlemak (OR, 2.18; 95\% Cl, 0.68 - 7.01; $p=0.19)$, makanan manis (1OR, 1.28; $95 \% \mathrm{Cl}, 0.70-2.35)$ ), dan makanan asin (OR, 1,04; 95\% Cl, $0,40-2,71 ; p=0,92)$. Tiga makanan dan minuman lokal teratas yang dikonsumsi oleh para siswa adalah Cireng (makanan goreng lokal yang terbuat dari tepung), teh, dan pizza (masing-masing dengan frekuensi 0,561, 0,429, 0,245 /hari).
\end{abstract}

Kesimpulan: Konsumsi makanan ringan lokal yang dijual di SMK di Kota Bekasi tidak memiliki hubungan yang signifikan terhadapt kejadian obesitas.

KATA KUNCI: kebiasaan mengemil; obesitas pada remaja; konsumsi makanan

\begin{abstract}
Background: Prevalence of overweight and obesity in adolescents (13 - 15 years) significantly increased from $7.3 \%$ in 2013 to $13.5 \%$ in 2018. The availability of many fast-food restaurants, both local and commercial, nearby the school increases the number of young people exposed to unhealthy food, especially those living in urban areas.

Objectives: This study examined the impact of local unhealthy snacks available in the school on adolescent obesity.

Methods: This was a cross-sectional study conducted in the five Secondary Vocational School in Bekasi, Indonesia. A total of 225 students aged 16-18 years were observed for their nutritional status and snack consumption. Body mass index for age indices was used to determine the obesity status of adolescents, classified as obese (>2SD) with respect to their age and sex using 2007 WHO reference charts. Students were asked about their food consumption using a semi-quantitative questionnaire. Odds ratios (ORs) was calculated for each type of snacks and $p<0.05$ was considered statistically significant.
\end{abstract}


Results: Finding of this study shows that $32.4 \%$ of students were obese. The consumption of local snacks associated with obesity included fatty food (OR, 2.18; 95\% Cl, 0.68-7.01; $p=0.19)$, sweet food (OR, 6.98; $95 \% \mathrm{Cl}, 3.00-16.25 ; p<0.001)$, and salty food (OR, 1.04; $95 \% \mathrm{Cl}, 0.40-2.71 ; p=0.92)$. The top three of local foods and beverages consumed by the students were Cireng (a local fried food made from starch), tea, and pizza (with frequency/day 0.561, 0.429, 0.245, respectively).

Conclusion: Local snacks on sale in the vocational schools in Bekasi City was not significant associated with obesity.

KEYWORDS: snacking behavior; obesity in adolescence; food consumption

\section{INTRODUCTION}

A recent report by the Lancet illustrated that the prevalence of obesity among children and adolescents (aged 5-19 years) rose more than tenfold within four decades. Although the prevalence of underweight children and adolescents was still higher, it is estimated that in 2022 obesity problems outweigh moderate and severe underweight among this population (1). Obesity in youth will increase the possibility of being obese in adulthood, increasing the risk of non-communicable diseases (NCDs) (2).

Currently, the obesity problem not only does affect people in developed countries but also in developing countries. A systematic review reported that, in Asian countries, the prevalence of overweight and obesity was $23.2 \%$ stemming from $14.6 \%$ for overweight and $8.6 \%$ for obesity (3). From this study, it is found that obesity prevalence was higher in boys than girls. In 2013, the Indonesian basic health research survey has reported that the prevalence of overweight/obesity was $7.3 \%$ and escalated to $13.5 \%$ in 2018 . This number was higher in girls compared to boys $(4,5)$.

It is well established that obesity is mainly caused by imbalanced energy and nutrient intake affected by unhealthy behavior (6)at leisure, during travel, and in the home are equally shifting rapidly toward reduced energy expenditure. Large-scale decreases in food prices (eg, beef prices. Therefore, it is important to review what is the major cause of why people promote unhealthy behavior including consuming unhealthy foods. Growing evidence in the literature indicated that food choice is responsible for adolescent obesity (7)concerns about adverse health outcomes in adolescents continues to rise. The complexity and expense of this problem require early recognition and specific preventive treatments. Knowledge of genetics and determinants of food choices contributing to adolescent obesity warrants further examination. The primary goal was to appraise the literature from the past decade (20072017. Food choices can be determined by many factors, such as culture and ethnicity, stress, siblings and family relationship, socioeconomic status, and genetic. In addition to that, policy support in order to maintain a healthy environment and tackling obesity is necessary (8). However, most urban areas in developing countries are exposed to unhealthy foods and these foods are widely available, including in the school environments. Although there is already a food guideline for schoolchildren snacks to achieve balanced nutrition, this guideline tends to be neglected by school policyholders. Lack of studies measuring the effect of unhealthy food sold surrounding the school may cause less attention from the school to this problem. This study examined the impact of local unhealthy snacks available in the school on adolescent obesity.

\section{MATERIALS AND METHODS}

This study was a cross-sectional conducted in the five secondary vocational schools (SMK) in Bekasi, Indonesia. These schools were SMK no 2 Bekasi, SMK no 3 Bekasi, SMK no 5 Bekasi, SMK Bina Karya Mandiri, and SMK Bina Husada Mandiri. The first three schools were the schools owned by the government, while the rests were private schools. Schools was selected by top three of highest population of adolescent girls. The total sample of those schools was 345 students, selected by purposive sampling with criteria determined 
by age (15-18 yo), gender (girls), health status, and willingness to be a sample. Of 345 students, however, we could only get 225 students for further analysis.

Data collected was characteristics, nutritional status, and snack consumption using primary data. The characteristics of the respondents were age, allowance, socio-economic status of the parents and measured with a validated questionnaire. Meanwhile, snack consumption was measured using a validated semi-quantitative food frequency questionnaire (FFQ) and nutritional status was determined by measuring body weight and height (Body mass index) according to age and gender (5). Snacks was categorized into fatty (contains fat or fried process food, fast food and or calory food) $(9,10)$, sweet (contains sugar) (11) and salty (contains sodium or salt) $(10,11)$ and determined as often (2 or more portion/day or rarely less than 2 portion/day) (5).Body mass index for age indices was used to determine the obesity status of adolescents, classified as obese (>2SD) with respect to their age and sex using 2007 WHO reference charts. Odds ratios (ORs) were calculated for each type of snacks and $p<0.05$ was considered statistically significant. In this research obese category was included overweight status.

This research was ethically approved and declared from Komisi Etik Penelitian Kesehatan Universitas Muhammadiyah Prof. Dr. Hamka, Jakarta, Indonesia with ethical approval number 03/19.01/002.

\section{RESULTS}

Table 1 describes the characteristic of the participants. It can be seen that the majority of participants was 17 years $(64.9 \%)$ with snack allowance with $>15,000-20,000$ IDR (33.3\%). Of 225 students, $32.4 \%$ were obese.

The risk of obesity due to unhealthy snack consumption is shown in Table 2. The consumption of local snacks associated with obesity included fatty food (OR, 2.18; 95\% Cl, $0.68-7.01 ; p=0.19$ ), sweet food (OR, 1.28; $95 \% \mathrm{Cl}, 0.70-2.35) ; p<0.42$ ), and salty food (OR, 1.04; $95 \% \mathrm{Cl}, 0.40-2.71 ; \mathrm{p}=0.92)$.

Table 3 indicates the top three of snacks from each snacks group consumed frequency by the students. Among those groups, Cireng from the salty

Table 1. Characteristics of participants

\begin{tabular}{lcc}
\hline \multicolumn{1}{c}{ Characteristic } & Over-Obese $\mathbf{n}(\%)$ & Non-OverObese $\mathbf{n}(\%)$ \\
\hline Age & & \\
16 years & $20(32.8)$ & $41(67.2)$ \\
17 years & $48(32.9)$ & $98(67.1)$ \\
18 years & $5(27.8)$ & $13(72.2)$ \\
Snacks allowance & & \\
$<5,000$ IDR & $0(0)$ & $4(100)$ \\
$5,000-10,000$ IDR & $13(20.3)$ & $51(79.7)$ \\
$>10,000-15,000$ IDR & $25(40.3)$ & $37(59.7)$ \\
$>15,000-20,000$ IDR & $14(18.7)$ & $61(81.3)$ \\
$>20,000$ IDR & $(11(55)$ & $9(45)$ \\
Mother's education & & \\
Never school & $4(33.3)$ & $8(66.7)$ \\
Primary school & $15(34)$ & $29(66)$ \\
Secondary school & $10(27)$ & $27(73)$ \\
Tertiary school & $31(27)$ & $84(73)$ \\
Academy and higher & $4(23.5)$ & $13(76.5)$ \\
Father's education level & & \\
Never school & $6(54.5)$ & $5(45.5)$ \\
Primary school & $10(27)$ & $27(73)$ \\
Secondary school & $7(28)$ & $18(72)$ \\
Tertiary school & $31(25.6)$ & $90(74.4)$ \\
Academy and higher & $11(35.5)$ & $20(64.5)$ \\
Total & $73(32.4)$ & $152(67.6)$ \\
\hline
\end{tabular}


Table 2. A risk factor of obesity due to fatty, sweet, and salty snacks

\begin{tabular}{lcccc}
\hline \multicolumn{1}{c}{ Snacks } & $\begin{array}{c}\text { Obese } \\
(\mathbf{n = 7 3 )} \mathbf{n}(\%)\end{array}$ & $\begin{array}{c}\text { Non-obese } \\
(\mathbf{n = 1 5 2 )} \mathbf{n}(\%)\end{array}$ & OR (95\% CI) & $\mathbf{p}$ \\
\hline Fatty & $6(50)$ & $6(50)$ & $2.18(0.68-7.01)$ & 0.19 \\
$\quad$ Often & $67(31.5)$ & $146(68.5)$ & & \\
$\quad$ Rarely & & & & \\
Sweet & $24(36.4)$ & $42(63.6)$ & $1.28(0.70-2.35)$ & $<0.42$ \\
$\quad$ Often & $49(30.8)$ & $110(69.2)$ & & \\
$\quad$ Rarely & $49(33.3)$ & $14(66.7)$ & $1.04(0.40-2.71)$ & 0.92 \\
Salty & $7(32.4)$ & $138(67.6)$ & & \\
$\quad$ Often & $66(32)$ & &
\end{tabular}

snack group is the most frequent food consumed by the adolescent students $0.56 \pm 0.17$.

Table 3. The top three snacks consumed frequency for each snacks group

\begin{tabular}{clc}
\hline \multicolumn{1}{c}{ Group } & \multicolumn{1}{c}{ Foods } & $\begin{array}{c}\text { Mean } \pm \text { SD } \\
\text { per day }\end{array}$ \\
\hline Fatty snacks & Pizza & $0.24 \pm 0.13$ \\
& Meatball & $0.18 \pm 0.27$ \\
\multirow{2}{*}{ Sweet snacks } & Curry & $0.15 \pm 0.08$ \\
& Tea & $0.43 \pm 0.66$ \\
& Candy & $0.37 \pm 0.81$ \\
Salty snacks & Doughnut & $0.19 \pm 0.61$ \\
& Cireng (a local fried food & $0.56 \pm 0.17$ \\
& made from starch) & \\
& Cimol (a local fried food & $0.49 \pm 0.19$ \\
& made from starch) & \\
& Pastel & $0.48 \pm 0.16$ \\
\hline
\end{tabular}

\section{DISCUSSIONS}

The main finding of this study indicates that students who often eat fatty, sweet, and salty foods tend to be one to two times more likely to be obese than those who rarely eat fatty, sweets, and salty. Although lack of studies in investigating contributory factors of obesity in adolescents, several studies indicated that energy intake, lack of fruit and vegetable consumption, as well as a high frequency of fast-food consumption were associated with adolescent obesity (12-14)Nepal. Participants: A random sample of 360 students aged 16-19 years from eight schools was included in the study. Results: The prevalence of overweight among adolescent students was $12.2 \%$ (95\% Cl 8.9 to 15.5 . Poor economic status and parental choice may negatively affect the way children and adolescents to choose their food. Children and adolescents from low socio-economic tend to choose unhealthy food which is usually cheap. A study investigated, for example, a negative association between the price and the sugar content of beverages, suggesting a high accessibility of sugary drinks (15).

In contrast of the result, some evidence in children confirmed that junk food exposures, including sugar-sweetened beverages (SSBs), was associated with obesity in children (16). A study shows that energy-dense food and snacking were associated with childhood obesity (17). Another school-based study in Makassar city reported that $45.2 \%$ of primary school students always consume sugar-sweetened beverages (SSB). This study also reveals that students who consumed SSB more than once a day are 2 times likely to be obese than those consumed once or less in a day $(95 \% \mathrm{Cl}: 1.12-$ $3.60, p=0.025)(15)$. Therefore, to anticipate the risk of being obese for both children and adolescents, a healthy food environment should be improved in the school. Students should be strictly exposed by obesogenic foods by promoting the concept of a healthy canteen (8).

Another finding of this study shows that the consumption frequency of several types of salty snacks is relatively high. For example, the frequency of Cireng from the salty snack group consumed by students was higher compared to tea and pizza, the most frequent food consumed from sweet and fatty snack group $(0.56 \pm 0.17$, $0.43 \pm 0.66,0.24 \pm 0.13$, respectively). High dietary sodium intake from snacking, again, was associated with the poor economic status of the population, including adolescents. A recent survey in the US 
reported that the lowest household economic status had the largest intake of sodium from snacks (18), suggesting that salty snacks are also accessible in terms of price for poor society just like sweet snacks. Although salty snack consumption was not significant to the risk of adolescent obesity, long-term snacking behavior of high-salt foods may develop metabolic disorders, leading to obesity and diabetes (19).

In this study, the fatty snack was far from significant as the contributory factor of obesity among adolescents. In contrast, a study in mice shows that both high fat and high carbohydrate increased body weight after 16 weeks. This study had a limitation in terms of identifying the type of fat consumed by the students, whether predominated by saturated or non-saturated fat. Different fats and fatty acids potentially impacted the metabolism in a different way (20).

\section{CONCLUSION AND RECOMMENDATION}

This study concluded that among unhealthy snacks (fatty, sweet, and salty snacks) commonly sold in the schools in Bekasi city, No one from the snacks has significant associated with obesity. It is important for the schools to support a healthy environment and policy, promoting children to have healthy food in the school. The possible intervention that potentially contributes to the reduction of obesity in children and adolescents is through promoting a healthy canteen. However, further study is needed to provide evidence of best practices.

\section{ACKNOWLEDGEMENT}

We thank the teachers and students from the schools involved for their cooperation during the study.

\section{REFERENCES}

1. Bentham J, Di Cesare M, Bilano V, Bixby $H$, Zhou B, Stevens GA, et al. Worldwide trends in body-mass index, underweight, overweight, and obesity from 1975 to 2016: a pooled analysis of 2416 population-based measurement studies in
128.9 million children, adolescents, and adults. Lancet. 2017;390(10113):2627-42.

2. Biro FM, Wien M. Childhood obesity and adult morbidities. Am J Clin Nutr. 2010;91(suppl):1499S-1505S.

3. Mazidi M, Banach M, Kengne AP. Prevalence of childhood and adolescent overweight and obesity in Asian countries: A systematic review and meta-analysis. Arch Med Sci. 2018;14(6):1185-203.

4. $\mathrm{MoH}$. Laporan Nasional Riset Kesehatan Dasar (Riskesdas) tahun 2013. Jakarta, Indonesia; 2014.

5. MoH. Laporan Nasional Riset Kesehatan Dasar (Riskesdas) tahun 2018. Jakarta, Indonesia; 2019.

6. Popkin BM. Global nutrition dynamics: The world is shifting rapidly toward a diet linked with noncommunicable diseases. Vol. 84, American Journal of Clinical Nutrition. 2006. p. 289-98.

7. Campbell ET, Franks AT, Joseph P V. Adolescent obesity in the past decade: A systematic review of genetics and determinants of food choice. J Am Assoc Nurse Pract. 2019;31(6):344-51.

8. Australian Governments. Policies for tackling obesity and creating healthier food environments Executive summary Comprehensive address unhealthy. 2017.

9. Albers MJ, Harnack LJ, Steffen LM, Jacobs DR. 2006 marketplace survey of trans-fatty acid content of margarines and butters, cookies and snack cakes, and savory snacks. J Am Diet Assoc. 2008;108(2):367-70.

10. Vardavas $\mathrm{Cl}$, Yiannopoulos S, Kiriakakis M, Poulli E, Kafatos A. Fatty acid and salt contents of snacks in the Cretan and Cypriot market: A child and adolescent dietary hazard. Food Chem. 2007;101(3):924-31.

11. Byrd-Bredbenner C, Johnson M, Quick VM, Walsh J, Greene GW, Hoerr S, et al. Sweet and salty. An assessment of the snacks and beverages sold in vending machines on US post-secondary institution campuses. Appetite. 2012;58(3):1143-51.

12. Piryani S, Baral KP, Pradhan B, Poudyal AK, Piryani RM. Overweight and its associated 
risk factors among urban school adolescents in Nepal: A cross-sectional study. BMJ Open. 2016;6(5):1-6.

13. Rathnayake KM, Roopasingam T, Wickramasighe VP. Nutritional and behavioral determinants of adolescent obesity: A case-control study in Sri Lanka. BMC Public Health. 2014;14(1):1-6.

14. Asna AF, Perdana SiM, Amelia R, Syah $\mathrm{MNH}$. Anemia, Nutritional Status, and Dietary Patterns in Adolescent Girls of Vocational High School Students in Bekasi, Indonesia. In: ANNALS OF NUTRITION AND METABOLISM. KARGER ALLSCHWILERSTRASSE 10, CH4009 BASEL, SWITZERLAND; 2019. p. 280.

15. Arundhana AI, Najamuddin U, Ibrahim W, Semba G, Muqni AD, Haning MT. Why Consumption Pattern of Sugar-Sweetened Beverage is Potential to Increase the Risk of Overweight in School Age Children? Biomedicine. 2018;38(1):55-9.
16. Datar A, Nicosia N. Junk Food in Schools and Childhood Obesity. J Policy Anal Manag. 2012;31(2):312-37.

17. Nisak AJ, Rachmah Q, Mahmudiono T, Segalita C. Snacking Energy-dense Food Related to Childhood Obesity. J Nutr Food Sci. 2018;08(05):8-12.

18. Dunford EK, Poti JM, Popkin BM. Emerging disparities in dietary sodium intake from snacking in the US population. Nutrients. 2017;9(6).

19. Lanaspa MA, Kuwabara M, Andres-Hernando A, Li N, Cicerchi C, Jensen T, et al. High salt intake causes leptin resistance and obesity in mice by stimulating endogenous fructose production and metabolism. PNAS. 2018;115(12):3138-43.

20. Bray GA, Lovejoy JC, Smith SR, DeLany JP, Lefevre M, Hwang $D$, et al. The Influence of Different Fats and Fatty Acids on Obesity, Insulin Resistance and Inflammation. J Nutr. 2002;132(9):2488-91. 